\title{
Citation:
}

Article No.: 2198

Václavík, D. (2020). Role intelektuálů v procesu „ateizace“ české společnosti v druhé polovině 20. století a její transformace. Slavia Meridionalis, 20, Article 2198. https://doi.org/10.11649/sm.2198

\section{David Václavík}

Masarykova univerzita, Brno

https://orcid.org/0000-0002-5761-7445

\section{Role intelektuálů v procesu „ateizace“ české společnosti $v$ druhé polovině 20. století a její transformace ${ }^{1}$}

\section{Krátké historické exposé místo úvodu²}

Česká společnost bývá v mnoha výzkumech i v jakémsi „obecném vědomi““ považována za jednu $\mathrm{z}$ nejvíce ateizovaných společností v současném světě. Jako př́klad lze uvést data ze dvou reprezentativních výzkumů zaměřených na religiozitu evropských, potažmo světových společností. Jedním z nich je

1 Text vznikl v rámci řešení grantového projektu GAČR č. 18-11345S „Ateismus, volnomyšlenkářství a sekularizace v zemích střední a východní Evropy ve 20. a 21. století“.

2 Autor textu si dobře uvědomuje, že nejde primárně o historickou studii, ale studii na pomezí sociologické a diskurzivní analýzy. Příslušné historické pasáže si proto nenárokují, aby byly vnímány jako „hloubkové“ rozbory konkrétních historických období. Mají hrát spíše roli nezbytného kontextuálního backgroundu.

This work was supported by the the Czech Science Foundation (The project registration number 18-11345S). Competing interests: no competing interests have been declared.

Publisher: Institute of Slavic Studies, Polish Academy of Sciences.

This is an Open Access article distributed under the terms of the Creative Commons Attribution 3.0 PL License (creativecommons.org/licenses/by/3.0/pl/), which permits redistribution, commercial and non-commercial, provided that the article is properly cited. ๑ The Author(s) 2020. 
European Values Study z roku 2008 a druhým pak výzkum Global Index of Religiosity and Atheism (GIRA) z roku 2012. Podle prvního z nich se za přesvědčené ateisty deklarovalo téměř $17 \%$ českých respondentů. Vyšší podíl se $\mathrm{v}$ rámci zkoumaných zemí objevil pouze v populaci bývalé NDR (24\%). Ve druhé uvedené studii se Česká republika zařadila na 3. místo v žebř́íčku nejateističtějších zemí světa. Podle ní dokonce až 30 \% českých respondentů samo sebe charakterizovalo jako přesvědčené ateisty. Vyšší míra výskytu byla zaznamenána pouze v Japonsku (31 \%) a v Číně (47 \%). Pokud bychom však v tomto výzkumu sečetli procenta odpovědí u variant „přesvědčený ateista“ a „ne-nábožensky založený“, ocitla by se Česká republika na 1 . místě žebříčku (78 \%), následovaná Čínou (77 \%), Francií (63 \%) a Japonskem (62 \%).

Cílem toho článku není podat rozbor toho, jak rozumět těmto číslům a co si vlastně pod „typickým českým ateismem“ můžeme představit. Studií na toto téma bylo publikováno již poměrně mnoho (např. Hamplová, 2013; Nešpor, 2010; Václavík, 2010) a kromě toho jde o problém, který se poněkud vymyká zaměření tohoto časopisu. Já bych se spíše rád soustředil na jeden $\mathrm{z}$ nepřiliš probádaných aspektů „českého ateismu“, kterým je role intelektuálů v procesu jeho institucionalizace v druhé polovině 20. století. Než se však budeme věnovat tomuto problému, dovolil bych si udělat několik drobných, leč pro pochopení historického kontextu důležitých poznámek. Jedním z klíčových faktorů, které se podílely na tom, že postoje české společnosti vưči náboženství jsou velmi ambivalentní a výrazně se liší od postojů většiny společností v regionu stř̌ední a východní Evropy, jsou dramatické a v mnoha ohledech specifické sociální a demografické proměny, jimiž česká společnost prošla $\mathrm{v}$ průběhu 20. století.

Už období tzv. první Československé republiky (1918-1938) naznačilo, jakým směrem se budou postoje vůči náboženství a náboženským institucím vyvíjet. Za hlavní rysy je možné označit rostoucí nedůvěru v náboženské instituce, tendenci k privatizaci náboženství a narůstající náboženský indiferentismus. Vývoj v daném období také ukázal, že rozhodující roli př̀i proměně vztahu Čechů k náboženství hrálo vymezování se vůči dominantní katolické církvi, které se výrazně proměňovalo od druhé poloviny 19. století (srov. např. Fasora et al., 2007) a které vyvrcholilo po vzniku samostatné Československé republiky v roce 1918, jejíz politické elity spojovaly antikatolicismus s vymezováním se vůči habsburské monarchii. ${ }^{3}$ Nejdramatičtěji probíhal tento vztah v prvních

${ }^{3}$ Náboženská situace v nově vzniklém Československu byla poměrně komplikovaná. Naprostá většina jeho obyvatel, a to bez ohledu na jejich etnicitu, se hlásila ke katolické 
letech existence samostatného státu, tj. zhruba do roku 1925. Porovnání údajů ze sčítání lidu z let 1910 a 1921 ukazuje, že katolická církev v tomto období ztratila více než 1200000 členů (srov. např. Srb, 1998). ${ }^{4}$

Po 2. světové válce byly popsané trendy posíleny dvěma faktory: odsunem německé menšiny (cca 2,6 milionů lidí) z českého pohraničí v letech 1945-1947 a nastolením komunistického režimu v roce 1948. Důsledkem odsunu německého obyvatelstva ztratila obnovená republika významnou část obyvatelstva, které se většinově hlásilo ke katolickému vyznání. Odsun se však výrazně dotkl i dalších denominací (Německé církve augšpurského vyznání, Novoapoštolské církve a Starokatolické církve). Závažnější však byly demografické a socio-ekonomické změny, které s sebou přinesl. Souvislé území českého pohraničí (označované dříve jako Sudety) bylo v podstatě vylidněno a záhy znovu osídleno. Významnou skutečností bylo především to, že se znovuosidlování pohraničí odehrávalo shora řízeným přesunem jedinců a nikoli celých komunit jako např. při osidlování Slezska v Polsku. Tito noví přistěhovalci se často rekrutovali z nižších sociálních vrstev, měli nižšś vzdělání a politicky inklinovali spíše k levici. Nezř́dka šlo o lidi „politicky proveřené“, sympatizující s komunistickou stranou, v důsledku čehož byl mezi nimi vyšší počet lidí „bez vyznání“.

Uvedený způsob dosidlování původně etnicky německého pohraničí vedl ke zpřetrhání historických, rodinných a komunitních vazeb a k rozpadu lokální náboženské paměti. $V$ českém pohraničí tak nastala situace, jejímž typickým obrázkem byla nukleární rodina „zakotvená“ na místě jen první generací bez jakýchkoli vazeb $\mathrm{k}$ místu a místní komunitě. $\mathrm{V}$ důsledku toho tak téměř naráz vymizely lokální náboženské a kulturní tradice, jako např. poutě či kolektivní oslavy svátků. Vinou zpřetrhání sociálních vazeb k místu došlo i k postupné devastaci hmotných projevů náboženského života (kostelů, kaplí, božích muk). Došlo rovněž k intenzivnímu zásahu do náboženské infrastruktury, která $\mathrm{v}$ některých regionech vedla $\mathrm{v}$ podstatě $\mathrm{k}$ paralýze činnosti náboženských

církvi, ale politické elity, zejména české, se poměrně otevřeně hlásily k často militantnímu antikatolicismu. Zároveň významnou politickou roli v nově vzniklé republice hrály levicově orientované politické strany, především Československá sociálně demokratická strana, které měly blízko k soudobým antiklerikálním a antikatolickým hnutím. K dané problematice více viz např. Halas, 2000 či Kudláč, 2005.

4 Důležitou roli zde sehrál masivní výstup z katolické církve po roce 1918 (skoro 1,5 miliónu členů) a vznik národní Československé církve v roce 1920, která většinu ex-katolíků absorbovala (více viz např. Václavík, 2010). 
skupin. Ze svých farností musela odejít převážná část německých kněží. Ze stejných důvodů zanikla i řada klášterů. Tím byla výrazně připravena půda pro politicky motivovanou ateizaci české společnosti, která nastala s definitivním nastolením komunistického režimu na začátku roku 1948.

Jinak řečeno, komunistický režim vlastně „chytře“ navázal na některá historicky daná specifika a mohl tak v oblasti své náboženské politiky využívat již existující nálady a postoje velké části české společnosti. Přesto však potřeboval jakýsi ideologicky vhodný teoretický rastr, který by tyto postoje české společnosti vůči náboženství spojil s marxistickou ideologií. V tom mu, jak se ukázalo, pomohly koncepce několika významných intelektuálů, kteří vycházeli ve svých dílech a myšlenkách z marxismu. Bylo by ale velmi naivní a zjednodušující se domnívat, že díky tomu vznikl jakýsi neměnný ideologický krunýřr, který svíral české postoje vůči náboženství až do pádu komunistického režimu na konci roku 1989. Podrobnější analýzy ukazují, že osudy toho „ideologického rastru“ byly mnohem komplikovanější a barvitější, než se na první pohled může zdát. A právě jejich stručné představení je hlavním cílem této studie.

\section{1. fáze - Hledání a tápání}

Obnovení Československa po 2. světové válce znamenalo nejen znovunabytí ztracené samostatnosti, ale také fakt, že se Československo dostalo do sféry vlivu Sovětského svazu. ${ }^{5}$ Díky tomu ještě před únorovým převratem v roce 1948, kdy se Československo stalo definitivně politickým i ideologickým satelitem sovětského Ruska, výrazně posílila pozice marxisticky orientovaných intelektuálů. V tomto přechodovém období let 1945-1948 hráli hlavní úlohu prŕslušníci př̀edválečné generace marxisticky orientovaných myslitelů, jakými byli např. Z. Kalandra, K. Taige, Z. Nejedlý, L. Štoll či L. Svoboda (srov. napřr. Gabriel et al., 1995, s. 150). Pro ně bylo náboženství nicméně spíše jen okra-

${ }^{5}$ Politická závislost na Sovětském svazu poválečné politické garnitury se začala projevovat již během druhé světové války a potvrzená byla de facto již v průběhu první poloviny roku 1945 (např. v klíčovém politickém dokumentu té doby, tzv. Košickém vládním programu). Výrazně pak narůstala po prvních poválečných volbách, které se konaly v roce 1946, které definitivně potvrdily dominantní postavení Komunistické strany Československa. Únorový převrat v roce 1948 byl tak již jen vlastně potvrzením této situace. 
jovým fenoménem, kterému se věnovali zprostředkovaně ve svých analýzách dějin, zejména českých (Z. Nejedlý, L. Štoll) či proměn společnosti a kultury (Z. Kalandra či K. Teige). V prvním př́ípadě bylo náboženství chápáno a vykládáno v souladu fenoménem tzv. „českého pokrokářství“, antikatolicismu a antiklerikalismu jako antipokrokářský, ale také antihumanistický systém, jehož další pokračování je vlastně ahistorickou anomálií.

Pokud pak byly některé náboženské proudy (např. husitství či některé směry tzv. radikální reformace) chápány pozitivně, pak jedině proto, že byly považovány za sociálně inovátorské a v jistém smyslu svým důrazem na sociální rovnost a spravedlnost anticipující komunismus jako marxistický koncept ideální společnosti. To platí zejména pro interpretaci husitství v díle Z. Nejedlého. Ten ve své knize Komunisté, dédici velkých tradic českého národa (1946) postuloval značně kontroverzní, ale $\mathrm{v}$ době komunistického režimu velmi rozšiřenou tezi, podle níž jsou komunisté přímými pokračovateli husitských revolučních tradic.

Podobné úvahy rozvíjel i český historik Robert Kalivoda (1923-1989). Ve svých interpretacích navazoval především na práce publicisty Kurta Konrada (Konrad, 1964), ${ }^{6}$ který zřejmě patřil mezi první, kdo husitství považovali za nejstarší v řadě moderních revolucí a jako hlavní př́íčinu husitství postuloval „rozmach městské zbožní výroby“ (Kalivoda, 1961, s. 59). V návaznosti na Konrada a komparací se světovými revolucemi dospěl Kalivoda k závěru, že husitství bylo první revolucí raně buržoazního typu. K podobným závěrům došel i jeden z nejvlivnějších marxistických myslitelů tohoto období Z. Nejedlý a díky němu se pak na dlouhou dobu staly „závazným kánonem“. V jeho pojetí na husitské hnutí navázali ve svém „sociálním úsilí“ i tehdejší čeští komunisté (Nejedlý, 1946).

Přinejmenším v této přechodové době, kdy ještě nebyla česká společnost vystavena explicitní bolševizaci a sovětizaci, tak bylo možné propojovat marxisticky pojaté interpretace náboženství s nemarxisticky, často národovecky pojatým antikatolicismem a antiklerikalismem a vytvářet dojem, že jde vlastně o soustavné rozvíjení jednoho z nejvýraznějších rysů „českého myšlení“. „Př́ínos“ marxistů, jakým byl právě Z. Nejedlý, proto spočívá nikoli v nějakém

${ }^{6}$ Kurt Konrad (1908-1941) byl německým Židem pocházejícím z Třebíče, od roku 1928 členem Komunistické strany Československa. Vůbec jako první autor v rámci české historiografie se pokusil interpretovat husitství z hlediska marxistické kritické teorie v jeho závislosti na sociálně revolučních motivech. Patřil k jedněm z předních literárních marxistických kritiků a intelektuálů meziválečného období. 
systematickém promýšlení, ale především v uvádění ateistické ideologie do každodenního života poválečné české společnosti, a to pomocí „politicko-ideologického" mýtu o jakémsi přirozeném sklonu českého národa k antikatolicismu, jehož logickým pokračováním je i „současný český ateismus“ (srov. např. Václavík, 2010). Tato myšlenková konstrukce pak po roce 1948, kdy se komunisté plně a definitivně chopili moci, umožnila společensky přijatelně legitimizovat ostrá protináboženská a zejména protikatolická opatření. Ta byla vždy vedena tak, aby v nich byly církve představovány jako základna politických reakcionářů, bránící rozvoji „nové a spravedlivé společnosti“. Často byl přitom použit stereotyp katolické církve jako národně neloajální a sociálně nespravedlivé organizace, který znala česká veřejnost ve „zjemnělée“ podobě již ze začátku dvacátých let 20. století.

Další skupinu tvořili myslitelé, kteří se již před druhou světovou válkou odmítali ztotožnit s leninistickou a později stalinistickou interpretací marxismu, která od konce 20. let 20. století, kdy v Komunistické straně Československa definitivně zvítězilo prosovětské křŕdlo, byla dominantní a od poloviny 30 . let i jedinou př́pustnou variantou marxismu pro československé komunisty. Tito myslitelé hledali inspiraci u dalších marxistických myslitelů, jakým byl např. L. D. Trockij, či spojovali marxismus s Freudovou psychoanalýzou.

Mezi nimi vynikal Záviš Kalandra (1902-1950), ostrý kritik stalinismu. Ten vydal v roce 1947 dvojdílnou publikaci s názvem České pohanství (Kalandra, 1947a, 1947b), v níž se věnuje jednak rozborům nejstarších pramenů týkajících se českých dějin (tzv. Kristiánova legenda či Kosmova kronika) a jednak rozborům mýtů, které se pojí s nejstaršími českými dějinami. Právě tato část je s ohledem na jeho pojetí náboženství, které chápe poněkud v rozporu s převládající marxistickou interpretací více psychologicky a antropologicky, pro náš cíl velmi zajímavá. Kalandra totiž odmítá převládající „racionalizující interpretace mytických vyprávění o počátcích českých dějin, jejichž autoři jsou přesvědčeni, že pod mytickým balastem se nachází jakési historické jádro, pomocí kterého jsme schopni dozvědět se nějaké relevantní informace o nejstarších českých dějinách. Naopak, $\mathrm{v}$ souladu s tehdy velmi moderními antropologickými a psychologickými přistupy navrhuje, aby tyto př́běhy byly chápány jako nadčasové mýty, které přecházejí z pohanského období v inovované podobě do vznikající křestanské společnosti. Velmi známá a zároveň velmi kontroverzní je i jeho interpretace kultu sv. Václava, nejvýznamnějšího českého světce, který byl a je považován za čtvrtého historicky doloženého českého knížete. Podle Kalandry však sv. Václav nebyl žádnou historickou 
osobností, ale šlo vlastně o staré pohanské božstvo plodnosti, které bylo úspěšně akulturováno nastupujícím křestanstvím (Kalandra, 1947b, s. 533nn). Kalandra jako přesvědčený marxista samozřejmě nepochybuje o tom, že náboženství jako součást ideologické nadstavby odráží ekonomické, sociální a politické poměry socioekonomické základny a že s postupným odstraňováním třídních rozdílů zanikne, ale odmítá jeho jednorozměrné výklady jako primitivního a iracionálního explanačního systému. Jeho pojetí, které akcentuje i antropologické či psychologické rozměry náboženství, se tak víc blíží neomarxistickým výkladům známým např. $z$ děl některých představitelů Frankfurtské školy.

\section{2. fáze - Dogmatická jistota}

Únorový převrat v roce $1948 \mathrm{~s}$ sebou přinesl nejen definitivní nastolení komunistické diktatury a s ní ostrou anticírkevní a antikatolickou politiku, ${ }^{7}$ ale také konečné prosazení marxisticko-leninské verze ateismu jako jediné správné a akceptované. V této souvislosti je důležité zdůraznit, že vědecký ateismus, který je součástí učení marxismu-leninismu, byl považován ve srovnání s tzv. starým ateismem osvícenců a materialistů za ucelenou a úplnou podobu ateismu, za jeho $v y$ šši formu.

Hlavním úkolem vědeckého ateismu v Československu 50. a 60. let 20. století bylo vytvořit vědecký světový názor vycházející z filozofie dialektického a historického materialismu, který by se zároveň stal základním předpokladem nejen pro kritiku náboženství, ale i novou formou ateismu. Podle poválečného propagandisty vědeckého ateismu v Československu Arnošta Kolmana si lidstvo postupně vytvořilo vědu, jejímž cílem bylo zdůvodnění světového názoru, a touto vědou je vědecká filozofie, kterou podle něj vytvořili Karel Marx s Friedrichem Engelsem. Za tuto vědeckou filozofii považoval dialektický materialismus, který je podle něj podstatně odlišný nejen od jiných světových názorů, ale také i od ostatní filozofie, nebot' je tzv. vědeckou filozofií (Kolman, 1946, s. 4-6). Mar-

${ }^{7}$ Restrikce a pronásledování samozřejmě dolehly i na další náboženské skupiny, nicméně v mnohem menší míře než na katolickou církev. Důvodů bylo hned několik. Za prvé celé antikatolické tažení nebylo navenek prezentováno jako protináboženské. Dalším důvodem bylo to, že nekatolické denominace vzhledem $k$ počtu věřících nepředstavovaly pro komunistický režim zdaleka takové nebezpečí. V neposlední řadě měla většina nekatolických náboženských skupin tendence nalézt s novým režimem jakýsi kompromis, a proto se vůči němu stavěla mnohem otevřeněji. Dokonce s ním v některých oblastech spolupracovala. Více viz např. Václavík, 2010, s. 98-111. 
xistické pojetí vědy mělo být důsledně materialistické, stejně jako formulování, obhajoba a propaganda vědeckého světového názoru. Jeho představitelé byli přesvědčeni, že náboženství postupně vymizí z vědomí lidí a že „proces odumírání náboženství není něčím, co snad způsobují ateisté, ale je to objektivní, na lidské vůli nezávislý společenský proces. Probíhá tedy nutně a rovněž i tam, kde bezvěrci nemají na veřejný život téměř žádný vliv, kde nemají v ruce státní moc“ (Robek \& Sviták, 1961, s. 280). Podle nich právě věda a všeobecné socialistické uvědomění budou náhradou za ztracené ideje minulosti.

Jakkoli byla změna $\mathrm{v}$ postoji $\mathrm{k}$ náboženství a s ní spojené prosazování tzv. vědeckého ateismu zřejmá již brzy po komunistickém převratu v roce 1948, k nějaké tvrdé ateizaci společnosti, kterou procházela např. společnost sovětská či společnosti jiných sovětských satelitů (např. Albánie) nedošlo. Z pragmatických důvodů (slabá pozice komunistů na venkově či silné duchovní zázemí křestanské inteligence) byl tak celý střet předkládán především jako střet politický a ideologické důvody byly odsouvány do pozadí. Formálně se v „temných“ 50 . letech snažil komunistický režim předstírat náboženskou toleranci, jejíž součástí byla např̀. i stále komplikovanější možnost navštěvovat hodiny tzv. náboženství v rámci školní výuky.

Do toho vzorce zapadaly i aktivity komunistickou stranou ovládaných médií. Svoji roli zřejmě sehrálo i to, že předpokládané spolehnutí se na „tradiční “ české antipatie vůči náboženským institucím a nízkou participaci na náboženském životě, které bylo a stále mnohdy i je chápáno jako doklad vysoké míry ateizace české společnosti, se ještě na začátku 50. let ukázalo jako poněkud přehnané. Výsledky cenzu z roku 1950, ale i výsledky z interních šetření, ukázaly, že pozice církví a s ní i role náboženství v životech obyčejných Čechů a Češek je stále poměrně silná. Podle údajů $\mathrm{z}$ tohoto censu mírně poklesl počet katolíků, ale naopak stoupl počet př́slušníků jiných denominací, především Českobratrské církve evangelické a Československé církve. Hlavně ale znatelně poklesl počet těch, kteří se prohlašovali za „bez vyznání“, a to $\mathrm{z}$ více než $7 \%$ v roce 1930 na $4 \%$ v roce 1950 . Ve skutečnosti byl ale pokles ještě větší, protože podle údajů z roku 1930 se $\mathrm{k}$ možnosti „bez vyznání “ přihlásilo $10 \%$ obyvatel české národnosti ( $\mathrm{z}$ toho v Čechách $14 \%$ a na Moravě $4 \%$ ), ale pouze $3 \%$ Němců. ${ }^{8}$ To bylo pochopitelně v rozporu s cíli nového režimu, ale především s předpoklady, z nichž vycházel.

8 Podobně silná se v průběhu 50. let ukázala i role náboženských rituálů, když stále více než $60 \%$ narozených dětí bylo pokřtěno, většina sňatků byla církevních (61 \%), stejně jako naprostá většina preferovala církevní pohřby $(77 \%)$. 
Komunistický režim na to reagoval poměrně tvrdě a jednoznačně. Kromě konkrétních mocenských opatření, které měly ještě více omezit činnost náboženských skupin, ${ }^{9}$ se režim začal důsledněji věnovat „správné a zintenzivnělée ideologické výchově směrem k vědeckému ateismu. Součástí tohoto trendu byla např. likvidace všech spolků, které svým pojetím ateismu konkurovaly marxisticko-leninskému, tak také centralizace ideologické výchovy $\mathrm{k}$ ateismu do jedné instituce, která by byla pevně kontrolována a ovládána komunistickou stranou. Taková instituce vznikla podle sovětského vzoru v roce 1952 a nesla název Československá společnost pro šiření politických a vědeckých znalostí (dále jen Společnost), od roku 1965 se pak nazývala Socialistická akademie. Jejím oficiálním cílem měla být popularizace vědy a přibližování vědeckého pohledu na svět co možná nejširším společenským vrstvám. Fakticky šlo však v mnoha oblastech zejména o státem řízenou a komunistickou stanou kontrolovanou indoktrinaci, která se odehrávala zejména (ale nejen) v humanitních a společenských vědách, které v počátcích dominovaly. Tzv. vědecký ateismus se již od začátku činnosti Společnosti stal významným tématem a jeho propagaci byla věnována velká pozornost.

Aktivity Společnosti měly sehrát důležitou roli zejména v oblasti popularizace a šíření ateismu ve venkovských oblastech. Její představitelé si ovšem uvědomovali, že jednostranně zaměřená ateistická indoktrinace by pravděpodobně selhala, proto propagaci ateismu rozprostřeli do několika oblastí - od astronomie, přes biologii a ekonomii k historii a filozofii. Cíle popularizačních přednášek v těchto oblastech byly v zásadě dva. Ten první měl ukázat, že náboženské přesvědčení je v rozporu se závěry všech významných vědeckých disciplín. Ten druhý pak,

9 Šlo zejména o nová legislativní opatření, která katolickou církev i další náboženské skupiny podřídila striktnímu státnímu dozoru. Jejich základem byly zákony č. 217/1949 Sb., kterými se zřizoval Státní úřad pro věci církevní, a č. 218/1949 Sb. o hospodářském zabezpečení církví a náboženských společností. Prvním z nich vytvořil komunistický režim legislativní základ pro ideologické zásahy do činnosti náboženských společností a také pro personální kontrolu nad nimi. Zř́dil centrální instituci - Státní úřad pro věci církevní (SÚC) -, jejímž oficiálním cílem bylo „dbát o to, aby se církevní a náboženský život vyvíjel v souladu s ústavou a zásadami lidově demokratického zřízení“ $(\$ 2)$, ale která měla především dohlížet na všechny stránky církevního života, personální politikou počínaje a náboženskými obřady konče $(\$ 3)$. Pouze tento úřad měl pravomoc udělovat souhlas k vykonávání duchovní služby, což znamenalo, že musel souhlasit s jmenováním každého pretendenta na všechny duchovní posty. Nový kurz státu vůči náboženským společnostem symbolicky potvrdilo i (znovu)zavedení slibu věrnosti republice, který měli skládat všichni duchovní. K této problematice viz více Václavík, 2010, s. 100-105. 
že náboženství je brzdou dalšího rozvoje společnosti a je naprosto neslučitelné $s$ nově vytyčeným ideálem komunistického státu.

Členové Společnosti se ale významně účastnili i dalších aktivit komunistického režimu, které měly vést $\mathrm{k}$ „důslednější ateizaci české společnosti“ a které měly výrazně propagandistický charakter. K nim patřilo především vydávání knih, které otevřeně ateismus prosazovaly nebo byly alespoň jasně protináboženské, přičemž zodpovědní představitelé si dobře uvědomovali, že cestou není jen publikování odborných či populárně naučných textů, ale také textů beletristických, které budou svým obsahem korespondovat s hlavním cílem, tj. kritikou náboženství. $V$ této době tak znovu vyšly některé texty českého satirika a kritika katolické církve K. Havlíčka Borovského, ale i překlady knih, jakým byl román Střeček (The Gadfly) anglické spisovatelky E. L. Voynichové či kniha Ostrov Tučňáků (Penguin Island) A. France (Olšáková, 2014, s. 420n). ${ }^{10}$

\section{3. fáze - Od bojovného vědeckého ateismu $\mathrm{k}$ dialogickému marxistickému ateismu}

Teprve ve druhé polovině padesátých let začínají také systematicky vycházet ve větší míře publikace zaměřené na samotný ateismus a jeho propagaci. Je to možná poněkud paradoxní, ale v prvních sedmi letech komunistického režimu, které byly charakteristické tvrdými proticírkevními opatřeními, zatýkáním kněží, likvidací řádů a pronásledováním veřejně známých lidí hlásících se k náboženskému př́ístupu ke světu, nebyla publikována skoro žádná odborná ani populárně naučná práce zaměřená na ateismus. Pro propagandistické účely se tak používaly starší, zpravidla předválečné publikace. Nejprve šlo o překlady prací sovětských autorů, které také tvořily do konce padesátých let naprostou většinu vydaných děl s danou tematikou. Nicméně později se začínaly objevovat i texty mladé generace českých marxistů, kteří se v této době plně identifikovali s dogmatickou podobou marxismu-leninismu, byt později, jak bude ještě ukázáno, část $\mathrm{z}$ nich přešla na pozice jeho kritiky a dostala se tak

10 Je nutné podotknout, že v dobovém kontextu byly k antináboženské polemice využívány i klasické texty české a světové literatury, které žádné explicitní ateistické myšlenky a antináboženské motivy neobsahovaly. 
do sporu s oficiálním establishmentem. Patřili mezi ně zejména Ivan Sviták, Ivo Budil, Dušan Machovec ${ }^{11}$ a později také Erika Kadlecová.

První takovou prací je pravděpodobně kniha Klasikové marxismu-leninismu o boji s náboženstvím: Určeno propagandistům z oboru vědeckého ateismu (1955) nejvýraznějšího z této skupiny českých marxistických myslitelů Ivana Svitáka. Svitákův filozofický pohled byl zásadně formován během čtyřicátých let, kdy navštěvoval přednášky předních českých filozofů, a to jak nemarxisticky orientovaných (např. Jan Patočka), tak těch, kteří se otevřeně hlásili k marxismu (např. L. Svoboda, A. Kolman). Po roce 1948 se nicméně plně ztotožnil s marxismem a stal se jedním $\mathrm{z}$ jeho nejaktivnějších propagátorů $\mathrm{v}$ rámci své generace. Sviták považoval marxismus, resp. v této době marxismus-leninismus, za vyvrcholení humanistické tradice, která začíná v renesanci a jejímž hlavním cílem je osvobození člověka. Jednou z klíčových součástí tohoto procesu je zbavení se strachu z nadpřirozených sil, strachu, který odvádí lidskou pozornost od pozemského života a jeho vlastního vědomí (Sviták tento proces označuje jako obrat k světskosti) (Sviták, 1957). Podle svých pozdějších slov byly pro pochopení této skutečnosti důležité filozofické systémy jak některých renesančních humanistů (např. M. de Montaigne), tak osvícenců, jakými byl Holbach či Voltaire, a zejména pak Feuerbach, Marx a Nietzsche (Sviták, 1992, s. 32-33).

Podle Svitáka lidské dějiny v posledních staletích jsou dějinami postupné emancipace člověka jako svobodné a tvůrčí bytosti, které jsou doprovázeny postupným „uvolňováním“ vztahů k náboženství, které nakonec přechází v jeho kritiku. Na jeho začátku je nejprve kritika církve a některých forem dogmatické teologie, která je posléze doplněna o kritiku náboženského idealismu, a nakonec vrcholí fundamentální kritikou náboženství v dílech výše uvedených autorů, z nichž Sviták vyzdvihuje především Feuerbacha a Marxe. Ti podle něj nejlépe pochopili a odhalili samotnou podstatu náboženství jakožto lidského výtvoru, který byl využíván $\mathrm{k}$ manipulaci směrem k sociálnímu podrobení. Právě role náboženství při vytváření a udržování sociální nerovnosti bránily obecné emancipaci člověka spolu s iracionalismem náboženství. To jsou hlavní důvody, proč je třeba náboženství odmítnout a aktivně proti němu vystupovat. $V$ této souvislosti

11 Dušan Machovec byl bratrem dalšího významného myslitele, Milana Machovce, který se v šedesátých letech velmi angažoval v dialogu mezi marxismem a křestanstvím (viz dále). Dušan Machovec se věnoval především dějinám ateismu (soustředil se zejména na jeho antické podoby a transformace), a to $\mathrm{z}$ pozic marxistické interpretace dějin filozofie. 
pak Sviták zdůrazňuje, že to byl především Marx a jeho marxisticko-leninističtí následovníci, kdo odhalil tuto reakční podstatu náboženství. ${ }^{12}$

Je třeba říci, že na ostrém odmítání náboženství, které je pro Svitákovo myšlení v této době typické, se poměrně významně podílelo i jeho hodnocení role katolické církve v některých důležitých událostech moderních dějin. Vedle antimodernismu církve, který byl jeho oficiální politikou od poloviny 19. století, to bylo zejména mlčení vrcholných katolických představitelů v čele s papežem Piem XII. vůči nacismu a jeho zvěrstvům. Tento názor se následně vžil do povědomí české společnosti (avšak nejen díky Svitákovi) natolik, že ignoroval jakékoli statečné postoje katolické církve vůči fašismu během 2 . světové války. Zdárně tedy sloužil k upevňování přesvědčení, že katolická církev kolaboruje s politickou mocí v každé době a za všech okolností.

Důležitou součástí Svitákova pojetí tzv. vědeckého ateismu byl i jeho „praktický“ rozměr. Cílem totiž nebylo jen to, aby se vědecký ateismus stal „pouhým“ teoretickým rámcem (i když nejpropracovanějším a těžko zpochybnitelným) pro filozofickou kritiku náboženství, ale zejména to, aby se stal východiskem pro výchovu současného člověka, která by vedla k jeho definitivnímu osvobození, jemuž náboženství brání. Proto Sviták dával takový důraz na ideologickou práci, v níž důležitou roli přisuzoval popularizaci vědy a marxistické filozofie, které obě nutně vedou k přijetí ateistického světového názoru.

$\mathrm{V}$ podobném duchu k problematice ateismu přistupovali i další čeští marxisté té doby, $\mathrm{z}$ nichž ale většina nedosáhla Svitákovy erudice a de facto jen omílala tvrzení sovětských autorů a jejich pozornost se soustředila zejména na popularizaci ateismu. Výjimku tvořili snad jen dva autoři - Jiří Cvekl, který se ve své knize O protikladu vědeckého a náboženského světového názoru (1956) zajímavě vypořádává s kritikou rakouského jezuity Gustava Wettera vůči sovětské filozofii, a Dušan Machovec, který se věnoval dějinám ateismu (D. Machovec, 1963).

V pozdějších pracích vydávaných především v 60. letech začal být Sviták ale $\mathrm{k}$ dogmatickému marxisticko-leninskému vědeckému ateismu sovětského stř̀ihu

12 Právě marxistická interpretace náboženství v kontextu socioekonomických podmínek lidské existence je dle Svitáka to, co z ní dělá zatím nejdokonalejší filozofický nástroj pro formulování vědeckého ateismu. Např. Feuerbachovu kritiku náboženství jako produktu odcizení lidského vědomí v tomto duchu chápe jako výrazný krok vpřed při pochopení toho, co náboženství je, jak funguje, ale přesto ji považuje za příliš redukcionistickou a přehlížející klíčové faktory. Srov. např. předmluvu k českému vydání Feuerbachovy kličcové knihy Podstata křrestanství (Feuerbach, 1954). 
poměrně kritický, aniž by ovšem opustil pozice ateismu, kterému zůstal až do své smrti v roce 1994 věrný. Ostře se totiž vymezoval vůči zaměňování ateismu s protináboženským tažením komunistického režimu. To považoval za spíše za masovou politickou ideologii, kdežto ateismus chápal za specifický projev moderního myšlení, založeném na skutečném vědeckém pochopení náboženství a jeho fungování. Proto se v této době dožaduje toho, aby bylo náboženství a jeho proměny vědecky zkoumány a vysvětlovány s pomocí takových disciplín, jakou byla především sociologie (Sviták, 1964, s. 224). Jak trefně podotýká současný historik české sociologie Zdeněk R. Nešpor, považoval I. Sviták soudobý ideologický boj proti religiozitě nejen za bezúčelný, ale i odporující „skutečnému poznání Marxových a Engelsových myšlenek, které hovořily o nezbytnosti nadstavby $\mathrm{v}$ každém sociálním uspořádání a současně o složitějším vztahu náboženství a dalších „vyspělých“ ideologií (Nešpor, 2008, s. 291).

Svitákova kritika dogmatického pojetí vědeckého ateismu však nebyla $\mathrm{v}$ průběhu šedesátých let $\mathrm{v}$ českém marxistickém diskurzu ojedinělá. $\mathrm{V}$ této době dochází stran náboženství k poměrně výraznému zlomu. Zatímco část myslitelů spojených s oficiálními státními a stranickými strukturami stále reprodukovala marxisticko-leninská klišé, část $\mathrm{z}$ nich $\mathrm{v}$ důsledku společensko-politické situace, kterou s sebou přinesla kritika stalinismu po XX. sjezdu KSSS, začala své pojetí marxismu výrazně emancipovat od marxisticko-leninského dogmatismu.

Ještě dál zašli další marxističtí myslitelé, jakými byli Milan Machovec, Vítězslav Gardavský, Erika Kadlecová či Peluška Bendlová. Ti se v průběhu 60. let posunuli z pozice marxistických kritiků náboženství na pozice zastávající nutnost dialogu mezi marxismem a náboženstvím, zejména pak křestanstvím. Někteří z nich přitom oceňovali etiku a sociální rozměr křestanství (M. Machovec) (M. Machovec, 1972) či humanismus a existenciální rozměr soudobého křestanství (V. Gardavský) (Gardavský, 1967).

M. Machovec se k otázce dialogu dostává na přelomu 50. a 60. let, kdy začíná pod vlivem tehdejším politických událostí (XX. sjezd KSČ, Kubánská a Berlínská krize) přehodnocovat svoje dosavadní pojetí člověka a společnosti, jehož základem se stala obava o další osud lidstva konfrontovaného nebezpečím atomové anihilace, stejně jako pokračující fragmentarizací společnosti. Cestu k př̀ekonání těchto nebezpečí pro další osud lidstva vidí v dialogu, který chápe jako „nejvyšší formu vzájemné lidské komunikace, při které se ve vzájemném styku dvou (či více) lidí z obou stran vědomě usiluje o takovéto rozevření člověka člověku. Dialog je tedy jakási cílevědomá komunikace, resp. je diskuse 
bytostná, ve které se nasazují všechny vnitřní schopnosti partnerů, nejen jejich vědomosti či názory“ (M. Machovec, 1965). Dialog začíná u jednotlivce, ale nakonec by měl přerůst do celospolečenského dialogu, který bude zohledňovat všechna stanoviska na základě vzájemného porozumění.

Za dva klíčové systémy, které umožňují a rozvíjejí takovéto pojetí dialogu, považoval Machovec marxismus a křestanství, přičemž oba systémy spojuje jejich hluboký humanismus. Machovcův postoj ke křestanství (ale vlastně i k marxismu) byl poněkud ambivalentní. Jednoznačně odmítal náboženský výklad světa včetně jeho klíčových dogmat, které se týkaly např. posmrtného života. $\mathrm{Na}$ druhou stranu je náboženství a zejména křestanství podle něj systémem, který skvěle vystihuje lidské nitro a umožňuje hluboké pochopení humanity a morálky, které se odráží v křestanském pojetí svědomí (M. Machovec, 1965, s. 239). Právě humanismus křestanství a marxismu umožňuje navázání a rozvíjení vzájemného dialogu. Machovcovy názory na dialog mezi křestanstvím a marxismem jsou však poměrně známé, a to i mimo české prostředí. Rozhodně však nebyly ojedinělé. $K$ dalším výrazným zastáncům tohoto dialogu patřil V. Gardavský.

Gardavského postoj je sice jednoznačně ateistický, ale usiluje o nalezení skutečného ,já “, čímž myslí nalezení kořenů vlastní koncepce světa bez Boha, koncepce člověka bez mýtu. Pokusil se o poctivý vztah k provizoriu života, jak ř́ká, o život bez lákadel a náhražek, a to vzhledem k jediné jistotě lidského života, smrti (M. Machovec, 1965, s. 12). A právě tento fatalismus i prŕíklon $\mathrm{k}$ marxismu jej v jistém smyslu připodobňují k J. P. Sartrovi. Snad by i bylo možné Gardavského nazvat „českým Sartrem“.

Jeho myšlení nejobsáhleji reprezentuje monografie Bůh není zcela mrtev (1967), ve které bylo jeho primární snahou přistoupit k náboženství otevřeně, poznat ho a rozumět mu, stejně jako hledat $\mathrm{v}$ něm ideové souvislosti s marxismem. Pochopení marxismu a současné situace není podle něj možné na základě selektivního rozumění, ale je potřeba pochopit kořeny toho, „jak a proč věci jsou“. Proto také chápal marxismus jako filozofii, která vždy chce jít $\mathrm{k}$ podstatám věcí. Jedním z motivů tázání se po židovsko-křestanské kultuře mu snad byla i okolnost židovského původu Karla Marxe (M. Machovec, 1965, s. 32). Především se ale domníval, že bez pochopení křestanství není plně možné dospět k sebepochopení marxismu, který vznikl ve stejné kultuře, a je tedy v jistém smyslu jeho pokračováním.

Marxismus, ř́ká Gardavský, není ani pozitivismem, ani scientismem, ale ani racionalismem, a proto také musí mít i specifický vztah ke křestan- 
ství. Marxista je „přesvědčen, že křestanství jako náboženské hnutí není pro socialismus, jeho úkoly a cíle nezbytné. Ví však, že pro mnohé z těch, kteří v socialismu žijí a kteří ho budují nebo za něj teprve bojují, je ještě víra v boha nezbytná. Ví, že socialismus je přechod. Proto také ví, že bůh není ještě zcela mrtev" (M. Machovec, 1965, s. 14). Toto motto, inspirované Friedrichem Nietzschem, se promítlo i do názvu Gardavského knihy. $\mathrm{O}$ „smrti Boha“ nicméně soudil, že je heslem osvícenství, které se snad nejvýrazněji promítá právě do Nietzschovy filozofie, jejíž výpady proti křest̉anství ale považuje v literatuře za snad nejnenávistnější. Označil ji dokonce za vulgární antiklerikalismus, který je skutečnému ateismu, tedy marxismu a pravému marxistovi, cizí.

Gardavský podobně jako I. Sviták chápe totiž ateismus jako myšlenkový systém vedoucí k životnímu postoji, který se nevyvíjí lineárně a u kterého je vždy důležitá reflexe. Poukazuje přitom na fakt, že různé podoby novověkého ateismu (od osvícenského racionálně ateistického antiklerikalismu až reflexivnímu marxistickému ateismu) sice odráží konkrétní historické a sociální pohnutky jejich tvůrců, ale není možné je chápat jako do sebe zapadající a vzájemně se podmiňující stupně. Většina $\mathrm{z}$ nich př̀edstavuje reduktivní ateismus „jednoho problému“ (např. vystihující antropologický rozměr náboženství a na něm založenou ateistickou kritiku náboženství, s níž se můžeme setkat $\mathrm{v}$ díle L. Feuerbacha). Od těchto reduktivních forem novověkého ateismu se liší reflexivní ateismus vycházející z marxismu. Jeho základní charakteristikou je, že $\mathrm{k}$ fenoménu náboženství přistupuje $\mathrm{v}$ její celistvosti a snaží se $\mathrm{v}$ duchu známé Marxovy teze o náboženství jako výrazu skutečné bídy, která je zároveň protestem proti skutečné bídě, která končí zprofanovaným prohlášením, že náboženství je opium lidstva.

Gardavský ale odmítá chápat tyto Marxovy věty tak, že náboženství je pouhou fikcí či výsledkem iracionálních představ o světě. Takové pojetí náboženství a z něj vycházející ateismus chápe jako povýšenecký a stejně primitivní jako náboženství, které kritizuje. Marxovo označení náboženství za opium lidstva musí podle Gardavského chápat tak, že pokud „existují odcizující materiální, ekonomické, sociální poměry, utlačený člověk v nich může žít jen tak, že si vytvoří sféru vztahů, které přesahují postavení jeho bídy“ (M. Machovec, 1965, s. 158). Náboženství je pak jedním z možných uskutečnění tohoto přesahu, kterým může být ale jakákoli ideologie úniku, i nereligiózní. Náboženství má ale oproti jiným formám úniku tu výhodu, že je artikulovanou a institucionalizovanou formou úniku, a proto jeho kritická analýza je nezbytná jako východisko ke kritice tohoto světa. Reflexe vlastních ateistických východisek (tedy 
reflexivní ateismus, který Gardavský označuje jako emancipující se ateismus) je nezbytným předpokladem pro skutečný nereduktivní ateismus vedoucí $\mathrm{k}$ osvobozujícímu humanismu. V této souvislosti pak Gardavský představuje svoji velmi zajímavou a ve své době značně kontroverzní typologii ateismu, která značně nabourala převládající ideologii jednoho kompaktního ateismu typického pro „socialistického člověka“.

Podle Gardavského je třeba rozlišovat pět typů ateismu ${ }^{13}$ - praktický ateismus, konformní ateismus, antiklerikálnílantiteistický ateismus, abstraktně humanistický ateismus a konečně marxistický ateismus. Praktický ateismus je prŕíkladem nereflektovaného ateismu, jehož základem je lhostejnost či přesněji ideová indiferentnost. Gardavský takového ateistu označuje za ideového neznaboha, který je stvořen civilizačním procesem. $\mathrm{K}$ ateismu se hlásí proto, že je to pro něj jakási historická a společenská danost, ale ve skutečnosti jsou mu v zásadě tyto otázky cizí. Jeho důsledkem je jakási existenciální prázdnota, která nakonec vede $\mathrm{k}$ útěku $\mathrm{k}$ různým pseudohodnotám (např. konzumismu) či dokonce k moderním pseudonáboženským systémům, k nimž Gardavský řadí sportovní fanouškovství (Gardavský, 1967, s. 176n). Konformní ateismus je výsledkem snahy se přizpůsobit dobovým politickým požadavkům a často se projevuje deklaratorními postoji, které mají podtrhnout správnost a pravověrnost jejich nositelů. Ve skutečnosti jde ale jen o formální projevy, za nimiž se rovněž skrývá jistá forma lhostejnosti, zde doplněná o vědomí jisté povinnosti (jako komunista musím být ateista bez ohledu na to, co to znamená) (Gardavský, 1967, s. 180).

Třetí forma ateismu, antiklerikální/antiteistický ateismus je svým zpo̊sobem protikladem předchozího, protože vychází $\mathrm{z}$ vnitřního přesvědčení. Tímto přesvědčením je představa, že náboženství v institucionalizované podobě (antiklerikální forma) bylo a je věčnou překážkou v pokroku lidstva, resp. že náboženské představy (antiteistická forma) jsou jen primitivními a iracionálními představami světa, které definitivně vyvrací moderní věda. U obou těchto forem kritizuje Gardavský jejich redukcionismus, který v případě prvního ignoruje diferencovanou úlohu náboženství a jeho konkrétních projevů dějinách a $\mathrm{v}$ př́padě druhého vede nezř́́dka $\mathrm{k}$ deizaci ryze pozemského (Gardavský, 1967, s. 182).

13 Tato typologie se soustředila na ateistické postoje v tehdejší společnosti komunistického Československa a neměla pravděpodobně žádné obecné ambice. Uvedenou typologii představuje v závěru své knihy Bưh není zcela mrtev (Gardavský, 1967, s. 175-188). 
Předposledním typem je abstraktně humanistický ateismus. Ten je podle Gardavského nejčastěji východiskem z osobní náboženské krize. Na rozdíl od předchozích si je dobře vědom mnohovrstevnatosti a složitosti náboženství, ale zároveň jde o velmi elitářskou a individualizovanou formu ateismu, která přehlíží jeho politický a společenský rozměr. Ta naopak výrazně akcentuje poslední Gardavským představená forma ateismu, totiž ateismus marxistický, který je jediným skutečně reflexivním ateismem. Uvědomuje si historickou podmíněnost náboženství i jeho mnohotvárnost, odmítá zkratkovité výklady, ale zároveň upozorňuje na to, kde je náboženství skutečnou překážkou. Takový ateismus je způsobem myšlení, který může být pochopen jako první filozofie marxismu, jako jeho metafyzika (Gardavský, 1967, s. 188).

Gardavský i Machovec si ale v zásadě kladli společnou otázku, která se týkala postavení náboženství, zejména pak křestanství v moderním světě. V souvislosti s ní docházeli k závěru, že odpovědi, které současné křestanství dává (zejména pak některé proudy současné teologie - jako např. dialogická teologie či různé formy teologie dialektické), jsou vlastně velmi blízké odpovědím, které nabízí současný marxismus (srov. např. Landa, 2017, s. 246). Oba systémy se tak mohou vzájemně obohacovat. V zásadě tak došli k podobným závěrům, jako mnozí marxističtí myslitelé na západ od železné opony, např. E. Bloch (Bloch, 1954) ${ }^{14}$ či R. Garaudy (Garaudy, 1965). Vrcholem těchto tendencí bylo uspořádání mezinárodní konference v Mariánských Lázních v dubnu $1967 . .^{15}$

Tyto tendence odrážely jistou myšlenkovou liberalizaci, kterou Československá společnost procházela $\mathrm{v} 60$. letech. Zejména $\mathrm{v}$ jejich druhé polovině došlo i k výraznému zmírnění proticírkevní státní politiky a liberalizace se promítla i do skutečnosti, že v této době byli odsunuti do pozadí i dogmatičtí ateisté marxisticko-leninského střihu. Oficiální postoje vůči náboženství tak výrazněji formulovali progresivní marxisté. Vedle výše uvedených myslitelů jako Machovec či Gardavský to byla socioložka Erika Kadlecová, která se dokonce na konci 60. let postavila do čela Sekretariátu pro věci církevní na Ministerstvu kultury. ${ }^{16}$ I když nikdy neopustila ateistické názory, její prrístup se stále více

14 Bloch zde originálním způsobem analyzuje vztah mezi religiozitou a utopií a náboženství a marxismus tak propojuje prostřednictvím toho, co nazývá totalita naděje.

${ }^{15}$ Ke konferenci a jejímu historickému a ideologickému pozadí více viz Mervart, 2017, s. $61-86$.

16 Tato instituce nahradila v roce 1956 původně samostatný Úřad pro věci církevní, který byl zřízen jako centrální státní instituce v roce 1949. 
podobal nekonfesijně pojaté sociologii náboženství, s jejíž pomocí se snažila vysvětlit vztah mezi náboženstvím a společností, ale především transformace funkce náboženství v souvislosti s fenomény modernizace a sekularizace.

\section{Fáze - Tzv. normalizace a krize věrohodnosti vědeckého ateismu}

Jisté liberalizaci, byt prováděné v pověstných „mezích zákona“, udělala př́trž srpnová okupace a následná normalizace. Otevřené vedení Sekretariátu pro věci církevní Ministerstva kultury (PVC MK) bylo nahrazeno dogmatiky a státní politika znovu nabrala ostře anticírkevní a antináboženský směr. Velká část vstř́ícných kroků byla zrušena či pozastavena ${ }^{17}$ a náboženství bylo znovu chápáno jako jedna $\mathrm{z}$ hlavních překážek $\mathrm{v}$ dosažení konečného vítězství komunismu. $\mathrm{V}$ nově nastalé situaci považovaly normalizační struktury za nezbytné, aby vznikla instituce, která by se explicitně otázkám ateismu z pohledu oficiální marxisticko-leninské ideologie věnovala.

Taková instituce byla založena v době vrcholící normalizace v roce 1972 v Brně. Šlo o Ústav vědeckého ateismu, který byl součástí Československé akademie věd. ${ }^{18}$ Podle zakládacích dokumentů mělo jít o instituci zabývající se „empirickým výzkumem společenského vědomí se zvláštním zřetelem $\mathrm{k}$ problematice světového názoru, morálky, ateismu a náboženstvi'“' ${ }^{19}$ První ředitelem tohoto Ústavu byl jmenován jeden z předních českých odborníků na vědecký ateismus prof. Jiří Loukotka, který práce na téma vědeckého ateismu publikoval již na počátku 60 . let. ${ }^{20}$ Nově vzniklý ústav se však nepodílel pouze

17 Znovu byla např. zrušena teologická fakulta v Olomouci.

18 K dějinám tohoto ústavu a jeho činnosti viz více Václavík, 2007, s. 471-487.

19 Informace o archivu a dochované dokumenty $\mathrm{z}$ doby činnosti Ústavu vědeckého ateismu jsou k dispozici na Masarykově ústavu a Archivu Akademie věd ČR (Ústav etiky a religionistiky $\check{C} S A V$, Brno, n.d.).

${ }^{20}$ Jiří Loukotka patřil $\mathrm{k}$ předním brněnským marxistům. Z marxisticko-leninského stanoviska se zabýval dějinami českého myšlení, vztahem náboženství k umělecké tvorbě, proměnami katolických a protestantských filozoficko-teologických koncepcí, problematikou ateistické výchovy, sociálními funkcemi náboženství. Vše samozřejmě z pozic marxistického „vědeckého ateismu“. Z jeho perspektivy bylo náboženství interpretováno jako něco falešného, čemu není možné se věnovat jinak než tak, že budeme jeho „falešnost“ a fiktivnost odhalovat a tím ho překonávat. Srov. Loukotka, 1961. 
na „teoretickém“ vyvracení náboženství z pozic vědeckého ateismu či na jeho popularizaci, ale poskytl také zázemí pro nově vystupňovaný každodenní konflikt s méně loajálními členy jednotlivých církví. Pracovníci ústavu totiž vytvářeli odborné posudky a expertizy, na jejichž základě se určovala „ideologická “ prrípustnost textů připravovaných k publikaci, ale také hodnocení činnosti jednotlivých duchovních, které mohlo být a často také bylo používáno při odebírání tzv. státního souhlasu.

I přes úporné snahy normalizačního režimu, a to včetně výše uvedeného pokusu po institucionalizaci vědeckého ateismu, však díky specifické společenské a politické situaci po srpnu 1968 došlo spíše k jeho diskreditaci a postupnému „vyprchání“ jeho jisté intelektuální přitažlivosti, kterou měl pro významnou část českých intelektuálů v 50. a 60. letech. Tento fakt potvrdily i výzkumy, které vznikly $\mathrm{v}$ rámci oficiálních institucí, ale i nemnoho těch, které se objevily v opozičních kruzích. ${ }^{21}$

Podle výzkumu, který byl uskutečněn v roce 1979 Ústavem pro výzkum veřejného mínění, souhlasilo $s$ ateizační politikou státu pouze $15 \%$ dotázaných, kdežto celých 67 \% zastávalo názor, že je nejlepší si náboženství nevšímat. Jinými slovy řečeno, více než dvě třetiny české populace zastávalo vůči náboženství indiferentní postoj. Nebylo pro ně zásadním problémem, spíše znamenalo možnou komplikaci, které je lepší se vyhnout. Př́činou tohoto postoje nebyl jen politický oportunismus a pragmatismus „malého českého člověka" v době normalizace, ale také komunistickou mocí umně využitá tradiční averze a nedůvěra vůči náboženským institucím a organizacím. S jistou nadsázkou můžeme říci, že právě v době normalizace byl završen postupný přerod českého antiklerikalismu v náboženskou lhostejnost, podtrhnutou "rovnicí" - náboženství = náboženská instituce = problém.

Zajímavé informace o religiozitě $\mathrm{v}$ tomto období podávají některé výzkumy a šetření, které vznikly mimo oficiální struktury. ${ }^{22}$ Šlo zejména o výzkum, který provedl s pomocí svých spolupracovníků český sociolog Zdeněk Strmiska, žijící od roku 1968 ve Francii. Výsledky toho výzkumu zaměřeného na světonázorovou a hodnotovou orientaci byly zveřejněny v roce $1986 \mathrm{v}$ Tigridově Svědectví (Strmiska, 1986, s. 265-334). Výzkum není sice reprezentativní, ale podává velmi zajímavý obraz o proměnách v náboženském životě české spo-

${ }^{21}$ Následující část studie vychází zejména z mé knihy: Václavík, 2010.

22 Přehledný rozbor těchto šetření nabízí již několikrát citovaná studie: Nešpor, 2007, s. 431-434. 
lečnosti na konci reálného socialismu. Podle získaných údajů se téměř $17 \%$ respondentů považovalo za plně a dalších více než $19 \%$ za částečně věřící, což by znamenalo, že se počty lidí, kteří se explicitně považovali za nábožensky orientované, přiblížily hodnotám z konce 60 . let. Tuto sebeidentifikaci odmítlo něco málo přes $62 \%$ dotázaných. ${ }^{23}$ Nešlo přitom pouze o lidi ze starších generací a venkovských oblastí, ale poměrně dobré zastoupení bylo i u lidí středních generací a obyvatel měst. Naopak mladší generace oproti tomu vůči náboženství, stejně jako vůči oficiální marxisticko-leninské ale i dalším ideologiím, zastávala spíše odmítavé stanovisko. Ideologie jakéhokoli typu odmítlo $62 \%$ mladých.

Zajímavým zjištěním bylo rovněž to, že explicitní sebeidentifikace s náboženstvím narůstala se vzděláním. Vědomé přijetí „náboženské identity“ nicméně ani ve Strmiskově výzkumu neznamenalo nutnou identifikaci s náboženskou institucí a participaci na kultickém životě. Účast na náboženských shromážděních uvedlo jen něco málo přes $10 \%$ respondentů a účast ve výjimečných prrípadech či zájem o tato shromáždění asi $8 \%$ dotázaných. Téměř $80 \%$ oproti tomu uvedlo, že se takových aktivit neúčastní vůbec. I přesto mohl Zdeněk Strmiska na základě svých analýz tvrdit, že „schématické tvrzení, podle něhož je třeba odepsat náboženskou víru jako živou sílu v československé společnosti, se ukazuje jako mylné“ (Strmiska, 1986, s. 289).

Obecně je tak třeba konstatovat, že snaha komunistické moci prosadit vědecký ateismus jako ideologii, s níž se bude plně či alespoň výrazně identifikovat většina české populace, vlastně selhal. Příčin bylo jistě několik - počínaje ztrátou kredibility, do níž se komunistický systém dostal po roce 1968, a konče velkou nedůvěrou Čechů vůči jakýmkoli ideologiím, která je pro ně typická nejen ve sledovaném období, ale patří i k výrazným charakteristikám současné české společnosti. Výsledkem pak byla paradoxní situace, o níž byla částečně zmínka o několik stran výše - většina české populace vykazovala v průběhu 70. a 80. let jak nedůvěru ve státem prosazovanou ateizační politiku, tak zároveň v náboženství a náboženské instituce. Obojí se dostalo do kategorie „je lepší si toho nevšímat“.

Mnohem větším nebezpečím než zesilující tlak normalizační moci byla pro náboženské skupiny a pro náboženství obecně socioekonomická transformace

${ }^{23}$ Více respondentů odmítlo možnost identifikace s marxismem, komunismem a konzervatismem, naopak méně s demokracií, liberalismem, nemarxistickým socialismem. Srov. Strmiska, 1986, s. 284. 
české společnosti směrem ke společnosti konzumní. Tento trend podporovaný režimem a směřující ke vzniku tzv. gulášového socialismu vedl spolu s velkým rozčarováním $z$ krachu pražského jara k velkému nárůstu laxnosti české společnosti, $\mathrm{k}$ sílící tendenci individualizace života a k výraznému posílení materiálních hodnot v životě jedinců. Významnou roli sehrál také fakt, že na počátku normalizace se dostává do produktivního věku generace narozená po roce 1948, která prošla plnou indoktrinací komunistického režimu a během svého studia byla konfrontována s oficiální protináboženskou rétorikou.

Tento kontext samozřejmě velmi nahrával tomu, že se jednoznačně posílila skupina obyvatel majících vůči náboženství indiferentní postoj, často doplněný tradiční nedůvěrou vůči náboženským institucím. Jistý nárůst podpory náboženských institucí a náznaky obnovy náboženského života na konci 60 . let byl spojen s obecným očekáváním změny. S jeho nenaplněním dochází k výraznému poklesu jak účasti na náboženském životě, tak vlastní sebeidentifikace na základě náboženství, který bude trvat celá 70 . a většinu 80 . let. Těmito skutečnostmi byly mnohem více přitom postiženy největší nekatolické denominace, Církev československá husitská a Českobratrská církev evangelická. $\mathrm{V}$ př́padě Církve československé husitské je možné dokonce mluvit o krizi, kterou další roky pouze potvrdily.

Na druhou stranu se začaly objevovat i nové formy náboženského chování, které měly potenciál oslovit jistou část poměrně velké skupiny „nevyhraněných“. Šlo především o fenomény spojené s alternativními a často výrazně privatizovanými náboženskými skupinami, jejichž největší devízou se stávala jinakost a schopnost reagovat na potřeby jedince vysoce individualizované společnosti. Podhoubí pro složitý a ambivalentní postoj české společnosti vůči náboženství na přelomu tisíciletí tak bylo zformováno.

Jak jsme viděli, role zejména levicových intelektuálů při formování a následné snaze při prosazení jakési „učenecké “ verze ateismu byla komplikovaná a rozhodně ne jednoznačná. Jakkoli se tito myslitelé snažili propojit tradiční český antiklerikalismus a s ním spojený složitý vztah k náboženství s marxistickou verzí ateismu a v prvních desetiletích komunistického režimu se jim toto propojení snad i dařilo, postupně ztrácelo pel intelektuální přitažlivosti. Výsledkem pak bylo upadnutí do strnulého dogmatismu, který jen opakoval zavedené fráze, nebo hledání alternativ, které ale ve svém důsledku opouštěly rámec tzv. vědeckého ateismu. I přesto se ale některé koncepce či myšlenky vzniklé v kontextu tohoto typu ateismu staly součástí pomyslné „národní mytologie“, v níž jsou Češi nezřídka představování jako skeptičtí odmítači náboženství. 


\section{BIBLIOGRAFIE}

Bartoš, V. (2017). K předpokladům marxistického univerzalismu v díle Vítězslava Gardavského. In I. Landa \& J. Mervart (Eds.), Proměny marxisticko-křestanského dialogu v Československu (pp. 232-244). Filosofie.

Bloch, E. (1954). Das Prinzip Hoffnung. Aufbau Verlag.

Fasora, L., Hanuš, J., \& Malíř, J. (Eds.). (2007). Sekularizace českých zemí v letech 1848 - 1914. CDK.

Feuerbach, L. (1954). Podstata křestanství (Z. Sekal, Trans.). SNPL.

Gabriel, J., Nový, L., \& Zouhar, J. (1995). Česká filosofie ve 20. století: Směry, osobnosti, problémy. Masarykova univerzita.

Garaudy, R. (1965). De L'Anatheme au dialouge. Plon.

Gardavský, V. (1967). Bůh není zcela mrtev. Československý spisovatel.

Halas, F.X. (2000). Sekularizace v Evropě a vztah mezi náboženstvím a společností v první československé republice. In Společnost v přerodu: Češi ve 20. Století: Sborník referátů z cyklické konference Demokracie 2000 (pp. 117-135). Masarykův ústav AV ČR.

Hamplová, D. (2013). Náboženství v české společnosti na prahu 3. tisíciletí. Karolinum.

Kalandra, Z. (1947a). České pohanství: Vol. 1. Nejstarší prameny. František Borový.

Kalandra, Z. (1947b). České pohanství: Vol. 2. Osudy bohů. František Borový.

Kalivoda, R. (1961). Husitská ideologie. Nakladatelství ČSAV.

Kolman, A. (1946). Vědecký světový názor. Ústřední výbor Komunistické strany Československa.

Konrad, K. (1964). Dějiny husitské revoluce. NPL.

Kudláč, A. K. K. (2005). Příběh(y) Volné myšlenky. NLN.

Landa, I. (2017). Teologie smrti Boha a marxistický ateismus. In I. Landa \& J. Mervart (Eds.), Promény marxisticko-křestanského dialogu v Československu (pp. 245-275). Filosofie.

Loukotka, J. (1961). Zkušenosti z vědeckoateistické výchovy žáků. SPN.

Machovec, D. (1963). Dějiny antického ateismu. SPN.

Machovec, M. (1965). Smysl lidského života. SNPL.

Machovec, M. (1972). Jesus für Atheisten (P. Kruntorad, Trans.). Kreuz Verlag.

Mervart, J. (2017). Historické perspektivy křestansko-marxistického dialogu a konference v mariánských Lázních 1967. In I. Landa \& J. Mervart (Eds.), Promèny marxisticko-křestanského dialogu $v$ Československu (pp. 61-86). Filosofie.

Nejedlý, Z. (1946). Komunisté, dědici velkých tradic českého národa. Ústřední výbor KSČ.

Nešpor, Z. R. (2007). Empirické výzkumy (současného) náboženství v letech 1946-1989: Prolegomena k vývoji české sociologie náboženství v období marxistické dominance. Soudobé dějiny, 14(2-3), 399-438.

Nešpor, Z. R. (2008). Ne/náboženské naděje intelektuálů: Vývoj české sociologie náboženství. Scriptum. 
Nešpor, Z. R. (2010). Př́liš slábi ve víre: Česká ne/religiozita v evropském kontextu. Kalich.

Olšáková, D. (2014). Věda jde k lidu! Academia.

Robek, A., \& Sviták, I. (1961). Náboženství a kultura. In I. Budil (Ed.), Náboženství v životě jednotlivce a společnosti (pp. 261-281). Orbis.

Srb, V. (1998). Tisíc let obyvatelstva českých zemí. http://snem.cirkev.cz/download/Srb.htm

Strmiska, Z. (1986). Výsledky nezávislého průzkumu současného smýšlení v Československu. Svědectví, 20(78), 265-334.

Sviták, I. (1957). Cesty k překonání náboženství. Orbis.

Sviták, I. (1964). Otázky současného ateismu. Orbis.

Sviták, I. (1992). Devět životů. Sakko.

Ústav etiky a religionistiky ČSAV, Brno. (n.d.). Masarykův ústav a Archiv Akademie věd ČR. http://vademecum.mua.cas.cz/vademecum/PomPohled.action?ref=\%28\%5En\%29\%28\% 28\%28localArchiv\%2C\%5En\%2Chot_\%29\%28unidata\%29\%29\%28187\%29\%29

Václavík, D. (2007). Český ateismus ve dvacátém století: K vývoji a institucionalizaci v letech 1948-1989. Soudobé dějiny, 14(2-3), 471-487.

Václavík, D. (2010). Náboženství a moderní česká společnost. Grada.

\section{Rola intelektualistów w procesie „ateizacji” społeczeństwa czeskiego w drugiej połowie XX wieku i jej transformacja}

Artykuł dotyczy oddziaływania, rozwoju i zmian różnych form ateizmu w twórczości czeskich, zwłaszcza marksistowskich, intelektualistów w drugiej połowie XX wieku. Omawia również ich wpływ na opinię publiczną, przede wszystkim w obliczu narastania negatywnego stosunku do religii u dużej części czeskiego społeczeństwa. Opracowanie opiera się głównie na historycznych i dyskursywnych analizach dzieł głównych autorów od lat 50. XX wieku do roku 1989, a zwłaszcza tak ważnych postaci, jak Ivan Sviták, Milan Machovec czy Vítězslav Gardavský.

Słowa kluczowe: ateizm, materializm, antyklerykalizm, marksizm-leninizm, dialog, ateizm naukowy, ideologia, dyskurs 


\section{The (Transforming) Role of Intellectuals in the Process of the "Atheization" of Czech Society in the 2nd Half of 20th century}

The article deals with resonance, development, and changes in various forms of atheism in the works of Czech, especially Marxist, intellectuals in the second half of the 20th century. Attention is also paid to their influence on public opinion, especially in connection with a rise in negative attitude of a large part of the Czech public towards religion. The study is based primarily on historical and discursive analyses of the works of principal authors from the 1950s to 1989. Among the authors discussed are important figures such as Ivan Sviták, Milan Machovec, and Vítězslav Gardavský.

Keywords: atheism, materialism, anticlericalism, Marxism-Leninism, dialogue, scientific atheism, ideology, discourse

\section{Notka o autorze}

David Václavík (vaclav@phil.muni.cz) - magister i doktor filozofii i historii religii na Uniwersytecie Masaryka w Brnie; profesor nadzwyczajny religioznawstwa na Wydziale Humanistycznym Uniwersytetu Masaryka w Brnie i Wydziale Przyrodniczo-Humanistycznym i Pedagogicznym Uniwersytetu Technicznego w Libercu; sekretarz generalny Europejskiego Stowarzyszenia Studiów nad Religią w latach 2011-2014. Autor książek: Sociologie nových náboženských hnutí (2007), Př́ručka sociologie náboženství (wraz z Z. Nešporem, 2008), Náboženství a moderní česká společnost (2009), Religionistická typologie a taksonomie (2012), Proměny amerického náboženství (2013). Zainteresowania badawcze: nowe ruchy religijne, sytuacja religijna w Europie Środkowej, sytuacja religijna w Stanach Zjednoczonych, metodologia akademickiego studium religii.

David Václavík (vaclav@phil.muni.cz) - MA and PhD in philosophy and the history of religions from Masaryk University in Brno (Czech Republic); Associate Professor of Religious Studies at the Faculty of Arts of Masaryk University in Brno and Faculty of Education of Technical University in Liberec; SecretaryGeneral of the European Association for the Study of Religion between 2011 
and 2014. Author of the books: Sociologie nových náboženských hnutí [Sociology of the New Religious Movements, 2007], Přŕručka sociologie náboženství [Handbook of the Sociology of Religion, with Z. Nešpor, 2008], Náboženství a moderní česká společnost [Religion and Modern Czech Society, 2009], Religionistická typologie a taxonomie [Typology and Taxonomy in the Academic Study of Religion, 2012], Proměny amerického náboženství [Transformations of American Religion, 2013]. Research interests: new religious movements, religious situation in Central Europe, religious situation in the United States, methodology of the academic study of religions.

Publication History: Received: 2019-12-11; Accepted: 2020-03-08; Published: 2020-12-31 